\title{
Family Attitudes and Behavior toward Tuberculosis Prevention in the Lembang Health Center Area, West Sulawesi, Indonesia
}

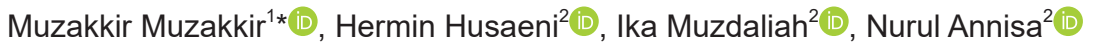 \\ ${ }^{1}$ Nursing Study Program, Nani Hasanuddin College of Health Sciences, Makassar, Indonesia; ${ }^{2}$ Nursing Study Program, Faculty \\ of Health Sciences, University of West Sulawesi, Majene, Indonesia
}

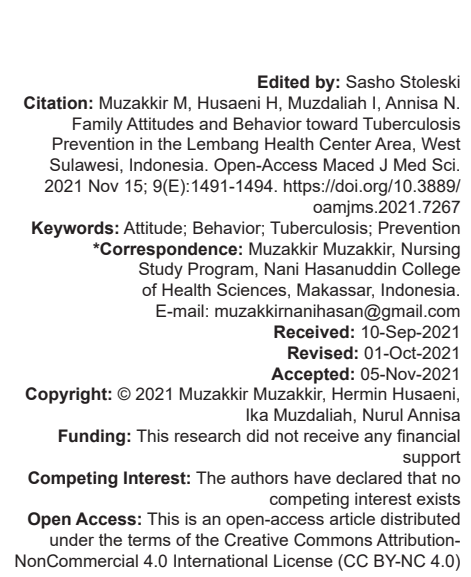

\section{Abstract}

BACKGROUND: People mostly have the perception that tuberculosis is an unexpected disease to occur because it greatly hinders family development. The existence of this disease tends to break social interaction. This perception will affect the attitudes and behavior of those who will prevent this disease from occurring in their families and environment.

AIM: This study aimed to determine the correlation between family attitudes and behavior with efforts to prevent infectious tuberculosis disease in the work area of Lembang Public Health, Majene, West Sulawesi.

METHODS: This quantitative research was conducted through a cross-sectional approach. Based on total sampling, as many as 31 respondents who were part of families with tuberculosis were involved as samples.

RESULTS: The bivariate analysis with the Chi-square test showed that the correlation between attitudes and TB prevention had a $p=0.301(\alpha=0.05)$. Then, the correlation of behavior with TB prevention had a $p=0.413(\alpha=0.05)$.

CONCLUSION: Thus, no significant correlation was identified between family attitudes and behavior toward tuberculosis prevention.

\section{Introduction}

Pulmonary tuberculosis (TB) is a disease caused by Mycobacterium tuberculosis [1], [2], [3], [4]. These anaerobic bacteria can live mainly in the lungs or various other organs with a high partial pressure of oxygen [5], [6]. These germs also have a high-fat content in their cell membranes, causing these bacteria to become resistant to acid, and the growth of the germs takes place slowly. Bacteria are not resistant to ultraviolet; therefore, transmission mainly occurs at night [7].

TB is currently still a public health problem both in Indonesia and internationally. It has become one of the goals of sustainable health development. Indonesia is the second country with the highest number of TB sufferers. It is nationally encouraging TB control to continue to be carried out with intensification, acceleration, extensification, and program innovation.

The incidence of TB in Indonesia in 2018 was $316 / 100,000$ population, and the death rate for TB patients was $40 / 100,000$ population. In 2019, the number of TB found was 543,874 cases, a decrease compared to all TB cases found in 2018 (566,623 cases). In West Sulawesi, $91.5 \%$ has exceeded the WHO standard, which is $>85 \%$. The estimated number of suspects in 2019 is still high at 17,329 [8]. Prevention must be conducted based on data/information sourced from the results of epidemiological analysis or the results of epidemiological observations/researchers [9].

The results of initial observations in several public health in Majene showed that people have a perception that TB is a disease that is not expected to occur because it greatly hampers the development of the family. People realize that this disease has significantly affected and can break the culture of that social interaction. This perception will affect their attitudes and behavior, which will prevent this disease from occurring in their families and environment [10].

However, the Lembang Health Center has launched many programs to prevent this disease, such as strengthening the leadership of the TB program in districts/cities. Besides, they also do promotion (advocacy, communication and social mobilization, regulation and increased financing, and program coordination and synergy), increasing access to quality TB services, improved TB service network through public-private mix, and others. However, it seems 
that other efforts are needed to maximize it by looking directly at the condition of the community, such as their attitudes and behavior.

Several studies found that family risk perception and attitudes may affect their behavior in preventing TB transmission. Attitude greatly influences a person's behavior. The better the attitude, the better the transmission prevention behavior carried out by an individual. This study aimed to determine the correlation between attitudes and behavior of the family with the prevention of infectious TB disease in the Lembang Health Center area, Majene Regency, West Sulawesi Province.

\section{Methods}

This research was conducted using a crosssectional approach. This research took place in the Working Area of the Lembang Public Health Center, Majene, during September-December 2020. All patients with TB in the working area of the Lembang Public Health Center were observed. Then, through the total sampling technique, 31 people were selected as samples. There were inclusion and exclusion criteria used as the basis for selecting the sample. The inclusion criteria consisted of being willing to participate in the study entirely and a family member of TB sufferers in the working area of the Lembang Health Center. Exclusion criteria were not willing to be involved in this study and not part of the family of TB sufferers in the Lembang Health Center work area.

The data used in this study were primary data and secondary data. Primary data were obtained directly from research subjects using a validated questionnaire. Then, secondary data were obtained from the disease report book in the working area of the Lembang Health Center. Data management was done using Microsoft Excel for Windows software. Furthermore, the data were analyzed with the help of SPSS for Windows vers 20 through the Chi-square test.

\section{Results}

The average age of TB sufferers was 39 years, a productive adult age. Most cases were 32 years old, dominated by males, high school education level, and work as a fisherman (Table 1).

Based on Table 2, the average attitude had a score of $37.9(\min =30, \max =45)$ and behavior was $32.7(\min =26, \max =39)$, meanwhile, the prevention efforts were $14.03(\min =10, \max =16)$. The value of
Table 1: Respondent characteristics

\begin{tabular}{lllll}
\hline & Age (y.o) & Gender & Education & Occupation \\
\hline $\mathrm{N}$ Valid & 31 & 31 & 31 & 31 \\
$\quad$ Missing & 0 & 0 & 0 & 0 \\
Mean & 39.35 & 1.45 & 3.16 & 3.87 \\
Median & 40.33 & 1.45 & 3.24 & 3.33 \\
Mode & 32 & 1 (Males) & 3 (Senior high school) & 1 (Fisherman) \\
Std. deviation & 14.21 & 0.51 & 0.89 & 2.58 \\
Range & 61 & 1 & 4 & 8 \\
Minimum & 14 & 1 & 1 & 1 \\
Maximum & 75 & 2 & 5 & 9 \\
\hline
\end{tabular}

attitude mode was 40 (median $=38.00$ ), the behavior was 34 (med = 33.45), and prevention efforts were 15 (med = 14.35). Thus, the attitude, behavior, and prevention efforts of respondents had exceeded the median variable data.

Table 2: Distribution of respondents on attitudes, behavior, and TB prevention

\begin{tabular}{llll}
\hline & Attitude & Behavior & TB prevention efforts \\
\hline $\mathrm{N}$ Valid & 31 & 31 & \\
$\quad$ Missing & 0 & 0 & 31 \\
Mean & 37.944 & 32.774 & 0 \\
Median & 38.000 & 33.455 & 14.032 \\
Mode & 40 & 34 & 14.353 \\
Std. deviation & 3.483 & 3.294 & 15 \\
Range & 15 & 13 & 1.622 \\
Minimum & 30 & 26 & 6 \\
Maximum & 45 & 39 & 10 \\
\hline
\end{tabular}

Based on Table 3, the p-value of attitudes to TB prevention was $0.301(\alpha=0.05)$. It means that there was no significant correlation between attitude and efforts to prevent TB.

Table 3: Correlation of attitudes to TB prevention efforts

\begin{tabular}{lll}
\hline & Attitude & TB prevention \\
\hline Attitudes & & \\
$\quad$ Correlation coefficient & 1.000 & -0.192 \\
${ }^{*} \mathrm{p}$-value & 31 & 0.301 \\
$\mathrm{~N}$ & & 31 \\
TB prevention & -0.192 & 1 \\
$\quad$ Correlation coefficient & 0.301 &. \\
${ }^{*} \mathrm{p}$-value & 31 & 31 \\
$\mathrm{~N}$ & &
\end{tabular}

Based on Table 4, the p-value of behavioral to TB prevention was $0.413(\alpha=0.05)$. It means no correlation between behavior and TB prevention efforts.

Table 4: Correlation of behavior to TB prevention efforts

\begin{tabular}{lll}
\hline & Behavior & TB prevention \\
\hline Behavior & & \\
$\quad$ Correlation coefficient & 1 & 0.153 \\
${ }^{*} \mathrm{p}$-value & 31 & 0.413 \\
$\mathrm{~N}$ & & 31 \\
TB prevention & 0.153 & 1 \\
$\quad$ Correlation coefficient & 0.413 & 31 \\
${ }^{*} \mathrm{p}$-value & 31 & 31 \\
$\mathrm{~N}$ & &
\end{tabular}

\section{Discussion}

\section{prevention}

\section{Correlation between attitude and}

Our observation showed no correlation between attitudes and efforts to prevent TB. It means 
that changes in attitudes will not affect the prevention efforts that patients with TB will carry out [11].

An individual's attitude is still a process of assessing an object or situation that provides a basis for people to respond or behave in a certain way, in which case the respondent will still have several choices to behave. This contradicts the research conducted by Wanma et al. (2020), which found a relationship between attitudes and prevention efforts in TB patients [12].

According to the attitude, we assumed that TB sufferers are in the cognitive and affective categories, and have not been manifested in the conative component of prevention. TB patients have perceptions and beliefs about the recommended prevention efforts in the cognitive and affective components. However, it is still hampered by enabling factors to manifest attitudes toward behavior in implementing prevention efforts. In this case, most respondents find it challenging to make prevention efforts using the same eating utensils as TB sufferers, increasing immunity by consuming nutritious food and cultural factors of the Majene community, which prioritize social interaction even with TB sufferers.

The level of attitude shown by the respondent is at the level of receiving and responding. TB patients received well information about $\mathrm{TB}$ prevention and succeeded in increasing their knowledge about TB prevention efforts. However, M. tuberculosis as a TB disease cannot be inhibited by only carrying out some prevention efforts by ignoring other prevention efforts. The level of attitude that must be adopted must reach the level of respect and responsibility for the attitude taken. If an individual reaches that level of attitude, every prevention effort will be carried out even if it takes risks. All prevention efforts must be fully implemented, especially in community groups who have a history of experiencing or being exposed to TB sufferers.

It should be noted that the efforts to prevent TB, according to Kemenkes (2018), are cultivating clean and healthy living behavior, cultivating ethical coughing behavior, maintaining and improving the quality of housing and its environment following healthy home standards, increasing body resistance, handling TB comorbidities, and implementing TB infection prevention and control in service facilities.

\section{prevention \\ Correlation between behavior and}

Our results showed no correlation between behavior and efforts to TB prevention. It means that the embodiment of behavior has not been entirely directed toward prevention efforts. Most of the behavior shown is a prevention effort. However, this effort has not been routinely implemented, especially in participating in health education, drying sleeping equipment used, consuming high protein foods, and throwing and placing masks that have been used anywhere. At the same time, this prevention point is a significant point for recommended prevention efforts.

Regularly participating in health counseling will increase knowledge, which ultimately helps increase an individual's awareness of the factors that cause TB disease [13], [14]. However, it is neglected because this activity takes up enough people's time, requires transportation costs, and a large amount of energy that can be used to carry out priority daily activities. It makes prevention efforts less desirable and implemented. On the other hand, health workers must participate in innovating to maximize health education efforts. Health education efforts should be carried out in health-care facilities and enter into other public spaces such as health promotion from public facilities, mass media, and social media. People who mostly have daily routines will still receive health information about TB disease.

Modifying the home environment is very important in preventing TB, one of which is by drying bedding which is one of the behaviors of a clean and healthy life [15]. By making this effort, M. tuberculosis bacteria attached to the bedding will die due to the effects of ultraviolet rays from the sun so that the growth of bacteria that cause TB in the family can be prevented. It also cannot be carried out routinely, which should be done 1-3 times a week by families of people with TB because it takes time and energy.

Masks are personal protective equipment that has been proven effective in preventing the transmission of TB in families and communities. However, it needs to be considered the correct way to use and to dispose of/ store. Disposing of masks in any place will increase the potential for transmission of $M$. tuberculosis bacteria to families. Moreover, it is stored in places always accessed by the family, such as rooms, living rooms, and kitchens. Masks should be disposed of in a closed trash can to prevent transmission of the bacteria that cause TB. This is still considered trivial due to a lack of knowledge about the procedures for using and storing it. Education on the use of masks must be intensified in the community, especially for patients and their families with TB, so that this prevention effort can be maximized in suppressing the transmission of TB.

Immunity must be maintained; most patients with previous TB are individuals with low immunity levels [16], [17]. Low immunity will trigger the development of $M$. tuberculosis bacteria in the body and/or make it easier for these bacteria to enter and grow in the body. This prevention effort can be made by consuming nutritious food every day. Consuming nutritious food every day can increase the quality of antibodies in the body that plays a role in maintaining and preventing the body from various diseases. The public does not realize this. Public perception about eating is still limited to overcoming hunger and satisfying the tongue with delicious food without regard to the nutritional composition needed to ensure optimal functioning of all body functions. However, balanced 
nutrition cannot be served by their families due to low economy condition

According to the researcher's assumption, the behaviors mentioned above are not optimally carried out routinely because TB patients know with a low level of understanding, which is a predisposing factor for implementing a behavior. Realizing attitudes with appropriate behavior are still influenced by the priority of other activities considered more important than prevention efforts. This tendency is a natural thing to happen in society. Society is still not ready to prioritize disease prevention. Perceptions that are built-in society are the result of behavior that must be seen and felt immediately. In comparison, prevention efforts are activities whose results are not easily realized but significantly affect oneself.

In addition, prevention efforts have not occurred optimal because they have not been supported by reinforcing factors, regulations, and supervision. In collaboration with health service institutions, the local government should establish regulations that regulate the environment and innovate in improving environmental health by modifying the cheaper and healthier environment. Supervision by health workers in collaboration with the government and the community can be carried out on vulnerable groups as reported by Kemenkes (2018), groups of infants, the elderly, low education, and low socioeconomic levels [8].

\section{Conclusion}

Attitudes or behaviors of families with TB disease were not correlated to TB prevent in the working area of the Lembang Health Center, Majene Regency, West Sulawesi.

\section{References}

1. Adigun R, Singh R. Tuberculosis. Treasure Island, FL: StatPearls Publishing; 2021

2. Jilani TN, Avula A, Gondal AZ, Siddiqui AH. Active Tuberculosis. Treasure Island, FL: StatPearls Publishing; 2021.

3. Zetola NM, Modongo C, Moonan PK, Ncube R, Matlhagela K, Sepako E, et al. Clinical outcomes among persons with pulmonary tuberculosis caused by Mycobacterium tuberculosis isolates with phenotypic heterogeneity in results of drugsusceptibility tests. J Infect Dis. 2014;209(11):1754-63. http:// doi.org/10.1093/infdis/jiu040

PMid:24443546
4. Miltgen J, Morillon M, Koeck JL, Varnerot A, Briant JF, Nguyen G, et al. Two cases of pulmonary tuberculosis caused by Mycobacterium tuberculosis subsp. canetti. Emerg Infect Dis. 2002;8(11):1350-2. http://doi.org/10.3201/ eid0811.020017

PMid:12453369

5. Aini DN, Arifianto A, Arifianto A. Description anxiety level of pulmonary TB patients. J Ners Widya Husada. 2020;7(2):71-8.

6. Via LE, Lin PL, Ray SM, Carrillo J, Allen SS, Eum SY, et al Tuberculous granulomas are hypoxic in guinea pigs, rabbits, and nonhuman primates. Infect Immun. 2008;76(6):2333-40. http://doi.org/10.1128/IAI.01515-07

PMid: 18347040

7. Tabrani R. IImu Penyakiy Paru. Jakarta: Trans Info Media; 2013

8. Kemenkes RI. Infodatin: Tuberkulosis. Jakarta: Kementerian Kesehatan RI; 2018.

9. Obito A. Penyakit Menular di Sekitar Anda. Jakarta: Pustaka Ilmu Semesta; 2015

10. Hager E, Odetokun IA, Bolarinwa O, Zainab A, Okechukwu O, Al-Mustapha Al. Knowledge, attitude, and perceptions towards the 2019 coronavirus pandemic: A bi-national survey in Africa. PLoS One. 2020;15(7):e0236918. http://doi.org/10.1371/ journal.pone.0236918 PMid:32726340

11. Kigozi NG, Heunis JC, Engelbrecht MC, van Rensburg AP, van Rensburg HC. Tuberculosis knowledge, attitudes and practices of patients at primary health care facilities in a South African metropolitan: Research towards improved health education. BMC Public Health. 2017;17(1):795. http://doi.org/10.1186/ s12889-017-4825-3 PMid:29017526

12. Wanma FR, Putra KP, Nusawakan AW. The relationship between the level of knowledge, attitudes and behavior of tuberculosis prevention in the Meyado district, Teluk Bintuni Regency, West Papua. J Keperawatan Muhammadiyah. 2020;5(2):5746.

13. Tolossa D, Medhin G, Legesse M. Community knowledge, attitude, and practices towards tuberculosis in Shinile town, Somali regional state, eastern Ethiopia: A cross-sectional study. BMC Public Health. 2014;14(1):804. http://doi. org/10.1186/1471-2458-14-804 PMid:25099209

14. Tola HH, Shojaeizadeh D, Tol A, Garmaroudi G, Yekaninejad MS Kebede A, et al. Psychological and educational intervention to improve tuberculosis treatment adherence in Ethiopia based on health belief model: A cluster randomized control trial. PLoS One. 2016;11(5):e0155147. http://doi.org/10.1371/journal. pone.0155147

PMid:27167378

15. Wahyuningtyas SM, Lestari ES, Mukono J, Sukmono E. The impact of environmental health services in primary health care on improving the behavior of pulmonary tuberculosis patients in Banyuwangi Regency. J Kesehatan Lingkungan. 2020;12(3):181-8.

16. Cooper AM. Cell mediated immune responses in Tuberculosis Annu Rev Immunol. 2009;27:393-422. http://doi.org/10.1146/ annurev.immunol.021908.132703 PMid:19302046

17. Mayer-Barber KD, Barber DL. Innate and adaptive cellular immune responses to Mycobacterium tuberculosis infection. Cold Spring Harb Perspect Med 2015;5(12):a018424. http://doi. org/10.1101/cshperspect.a018424

PMid:26187873 